Sains Malaysiana 47(10)(2018): 2359-2368

http://dx.doi.org/10.17576/jsm-2018-4710-12

\title{
Piper sarmentosum as an Antioxidant: A Systematic Review
}

(Piper sarmentosum sebagai Antioksidan: Ulasan Sistematik)

\author{
Siti MarJiana Ismail, Chua KiEn Hui, Amilia Aminuddin \& AZIZAH Ugusman*
}

\section{ABSTRACT}

Piper sarmentosum (PS) is an herb with various medicinal properties. The antioxidant activity of PS contributes to many of its pharmacological effects such as anti-hypertension, anti-cancer and anti-diabetes. This systematic review provides information regarding the antioxidant activity of PS. The review was conducted systematically to identify relevant published articles on the antioxidant activity of PS. The collected data was based on the searched articles through PubMed, Science Direct and Scopus databases between the years 1946 until March 2018. Only articles written in English and related to antioxidant activity of PS were included in this review. Based on the literature searched, 130 potential articles were identified and 19 articles met the inclusion criteria. Ten studies related to chemical assays, five studies combined in vivo animal and chemical assays, three studies combined chemical assays and in vitro studies and a single study combined chemical assay, in vitro and in vivo studies were included in this review. All studies showed positive effects of PS against oxidation, indicating the potential of PS as a source of natural antioxidant.

Keywords: Antioxidant; free radicals; free radical scavenging effect; oxidative stress; Piper sarmentosum

\section{ABSTRAK}

Piper sarmentosum (PS) merupakan sejenis herba yang mempunyai pelbagai manfaat daripada segi perubatan. Aktiviti antioksidan PS banyak menyumbang kepada kesan farmakologinya seperti anti-hipertensi, anti-kanser dan anti-diabetes. Ulasan sistematik ini menyediakan maklumat berkenaan aktiviti antioksidan PS. Ulasan dilakukan secara sistematik untuk mengenal pasti penerbitan yang berkaitan dengan aktiviti antioksidan PS. Data yang dikumpul adalah berdasarkan artikel yang dicari melalui pangkalan data PubMed, Science Direct dan Scopus antara tahun 1946 sehingga Mac 2018. Artikel berbahasa Inggeris yang berkaitan dengan aktiviti antioksidan PS dimasukkan ke dalam ulasan ini. Berdasarkan pencarian, sebanyak 130 artikel yang berpotensi telah dikenal pasti dan 19 artikel memenuhi kriteria inklusif kajian. Sebanyak sepuluh kajian asai kimia, lima kajian gabungan kajian asai kimia dan kajian in vivo, tiga kajian gabungan kajian asai kimia dan kajian in vitro dan satu kajian hasil gabungan asai kimia, kajian in vivo dan kajian in vitro terpilih di dalam ulasan ini. Kesemua kajian menunjukkan kesan positif PS terhadap pengoksidaan dan ini menandakan PS berpotensi sebagai sumber antioksidan semula jadi.

Kata kunci: Antioksidan; kesan pengaruh radikal bebas; Piper sarmentosum; radikal bebas; stres oksidatif

\section{INTRODUCTION}

Piper sarmentosum (PS) (Figure 1) is an herbaceous plant that belongs to the family of Piperaceae (Hussain et al. 2009). The vernacular names of PS vary among different countries. It is known as daun kaduk, wild pepper, wild betel or sirih duduk in Malaysia; karuk or sirih tanah in Indonesia; cha plu in Thailand; bo la lot in Vietnam; phak i leut in Laos and jia ju, xi ye qing wei teng or qing ju in China. The plant easily grows in shady areas (Hussain et al. 2012). It is glabrous and creeping with $40-50 \mathrm{~cm}$ height of procumbent branches (Rahman et al. 2016). The leaves are alternate, broadly ovate to elliptic with light to dark green colour (Arunrat et al. 2006). The leaves emit a pungent peppery scent when crushed and the size is $4.5-6 \mathrm{~cm}$ wide and 7.5-9.5 cm long (Arunrat et al. 2006).

PS has been widely used as food and traditional medicine especially in the South East Asian countries (Abd Jalil et al. 2012). The plant is consumed alone as culinary herb or in combination with other herbs. Traditionally, PS is used for medicinal purposes to treat cough, flu, rheumatism, fever, tooth pain, foot dermatitis, asthma and pleurisy (Abd Jalil et al. 2012; Lee et al. 2011). In Thailand, PS was used to treat minor wounds (Abd Jalil et al. 2012), as an expectorant or anti-diabetic agent (Hutadilok et al. 2006), digestive tonic or anti-malarial agent (Chanwitheesuk et al. 2005).

Oxidative stress happens when there is imbalance between oxidants and antioxidant defense mechanisms in the body (Sies 1997). Oxidative stress causes lipid peroxidation, DNA mutation, membrane protein damage and apoptosis; thereby leading to cancer, cardiovascular diseases and neurodegenerative disorders (Renugadevi $\&$ Prabu 2010). Antioxidants are substances that reduce or prevent oxidation by interfering with the transfer of electrons from a substance to an oxidising agent (Velioglu et al. 1998). The main function of antioxidants is to protect 


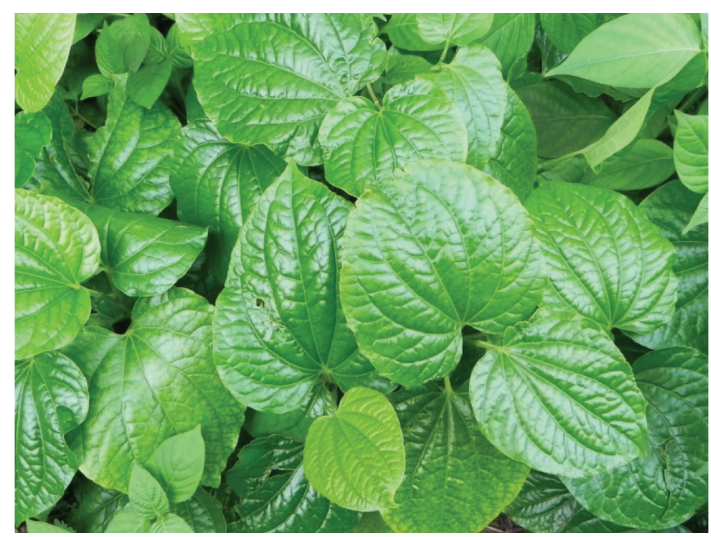

FIGURE 1. Piper sarmentosum

the body against free radicals damage. Endogenous antioxidants include glutathione, uric acid and bilirubin while antioxidant enzymes include superoxide dismutase (SOD), catalase (CAT) and glutathione peroxidase (GPX). In addition to endogenous antioxidants, optimal antioxidant status can also be achieved by consuming exogenous antioxidants from natural sources such as coffee, honey, tea, fruits and vegetables (Nur Syamsina et al. 2017).

Numerous studies showed that PS extracts exhibit antioxidant activities (Amran et al. 2011; Chanwitheesuk et al. 2005; Ugusman et al. 2012). Aqueous, methanol and hexane extracts of PS showed high antioxidant activities by reducing lipid peroxidation and protecting endothelial cells against apoptosis induced by oxidative stress (Hafizah et al. 2010). PS reduced inflammation and formation of atherosclerotic lesions in hypercholesterolemic rabbits through its antioxidant activity (Amran et al. 2011, 2010). Besides, PS reduced plasma cholesterol and attenuated hypertension in rats by reducing oxidative stress (Mohd et al. 2015). PS had anti-carcinogenic activity in human hepatoma cell line (Ariffin et al. 2009) and attenuated diabetes complications in streptozotocin-induced diabetic rats (Hussan et al. 2013).

The high antioxidant activities of PS are related to the amounts of total polyphenols and flavonoids in the extracts (Lee et al. 2014). Other antioxidant compounds found in PS are alkaloids, amides, pyrones, sterols and neolignans (Hussain et al. 2009) as well as vitamin C, Vitamin E and carotenes (Chanwitheesuk et al. 2005). The present systematic review is designed to summarize up-to-date researches on the antioxidant activity of PS. This review will provide meaningful baseline information for future work as well as commercialisation of the herb.

\section{MATERIALS AND METHODS}

\section{SEARCH STRATEGY}

A systematic literature searched was conducted to identify relevant research studies on antioxidant activity of PS. The method was based on the Preferred Reporting Items for Systematic Reviews and Meta-Analyses (PRISMA) checklist (Moher et al. 2015). The search for the research papers involved three databases; PubMed (http://www. ncbi.nlm.nih.gov/pubmed/), Science Direct (http://www. sciencedirect.com) and Scopus (https://www.scopus.com/) from 1946 to March 2018. The search strategy comprised of combinations of the following two keywords; 'Piper sarmentosum' and 'antioxidant' for the three databases. The references to all retrieved articles were reviewed for relevant citations.

\section{SELECTION CRITERIA}

Limitation of article type, publication status and language were compulsory. Only the original articles published in English language were included in this review. Review articles, books, chapter in books, conference proceedings, editorial letters, case studies and duplication of publication were excluded from this review. Studies using combined preparation of P. sarmentosum with other herbs were also excluded.

\section{ARTICLES SCREENING}

The articles screening process was done by two reviewers. A discussion was conducted to ensure that all reviewers agreed upon all exclusion and inclusion criteria selected. Data extraction processes was done according to PRISMA guideline (Moher et al. 2015). All the duplicate articles among the databases were removed. The first screening was based on exclusion criteria whereby articles published as a review, book, book chapter, editorial letter, conference proceeding or case study were sorted out based solely on their titles and abstracts. Secondly, published articles with lack of information on antioxidant activities related to $P$. sarmentosum were excluded. Finally, the remaining articles were assessed thoroughly for eligibility by checking all inclusion criteria.

\section{RESULTS AND DISCUSSION}

\section{DATA EXTRACTION RESULTS}

Overall, a total of 130 potential articles were found from the three electronic databases. Each article was assessed independently by two reviewers based on the inclusion and exclusion criteria. A total of 26 articles were removed due to duplicate between the three databases, leaving behind 104 articles. Forty articles related with reviews, editorial letters, short communication, conference abstract and book chapters were excluded. Another 45 articles did not contain any parameters related to antioxidant activity of PS. Thus, a total of 111 articles were sorted out after the first and second screening. The remaining 19 articles were selected for the final analysis and included in this review. A flowchart of the articles selection process is shown in Figure 2. 


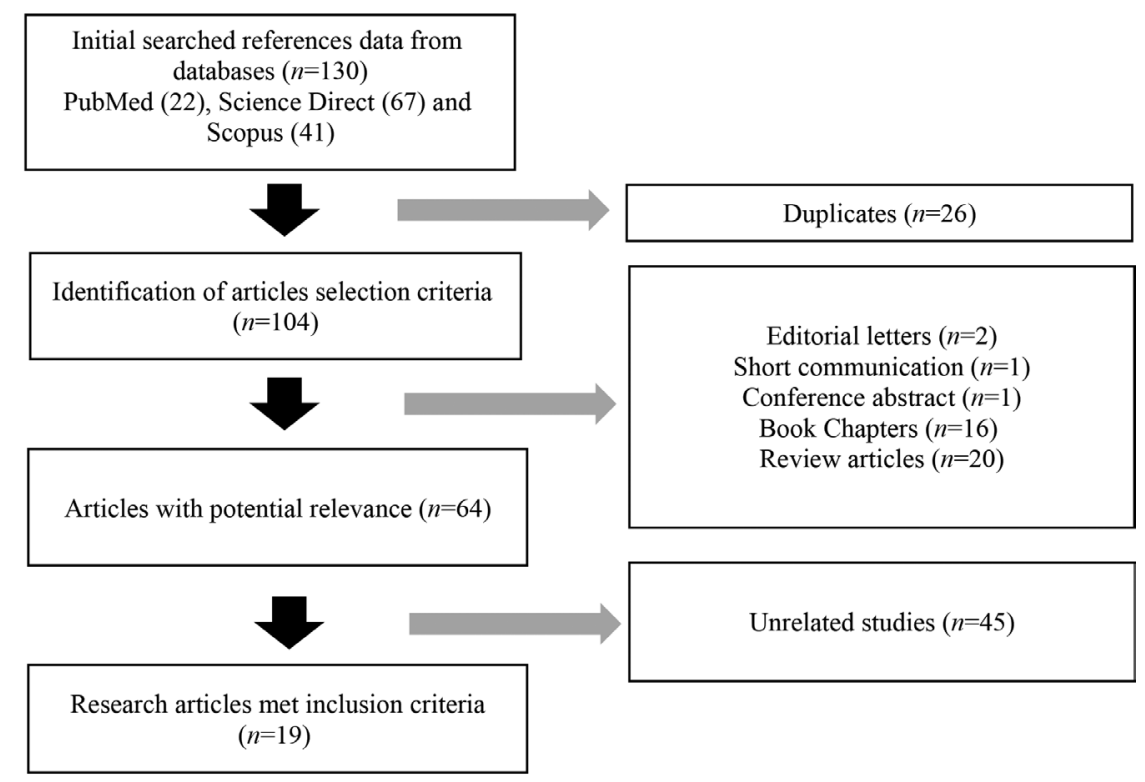

FIGURE 2. The selection process of the articles according to PRISMA guideline

\section{STUDY DESIGN CHARACTERISTICS}

All the final selected studies were characterised in Table 1 . These comprised of 19 studies published between years 2003 and March 2018. Ten of the studies focused on PS only while another nine were focused on multiple herbs or plants including PS. Based on the study design, this review consisted of a single study which combined chemical assay, in vitro and in vivo studies, three studies which combined chemical assays and in vitro studies, five studies which combined in vivo studies and chemical assays and ten studies using chemical assays.

Animal studies used Sprague Dawley rats (Hussain et al. 2010), Wistar rats (Azlina et al. 2011; Mohd et al. 2015), Balb/c albino mice (Lee et al. 2011), DurocLandrace-Yorkshire piglets (Wang et al. 2017) and New Zealand white rabbits (Amran et al. 2011) as the research models. There were five different cultured cells used for in vitro studies including human umbilical vein endothelial cells (HUVEC) (Hafizah et al. 2010), human lymphocytes cells (HLC) (Wan Ibrahim et al. 2010), murine monocytic macrophages cell line (RAW 264.7) (Lee et al. 2011), immortalised murine microglial cells (BV-2) and human neuroblastoma cells (SH-SY5Y) (Yeo et al. 2018).

Several antioxidant assays such as 1-diphenyl-2picrylhydrazyl (DPPH) radical scavenging assay, ferric reducing antioxidant power (FRAP) assay, hydroxyl radical scavenging (HRS) assay, B-carotene linoleate (BCL) assay, iron chelating activity (ICA), superoxide scavenging assay, 2,20-azino-bis-3-ethylbenzothiazoline-6-sulfonic acid diammonium salt (ABTS) assay, erythrocyte hemolysis assay (EHA) and bleomycin-dependent DNA damage (BDD) assay were used in the chemical assay studies. Biochemical parameters such as malondialdehyde (MDA), thiobarbituric acid reactive substances (TBARS), cell viability, superoxide dismutase (SOD), catalase (CAT) and glutathione peroxidase (GPX) activities were also measured as part of the antioxidant activities.
Besides, the contents of antioxidant compounds in the extracts such as total phenolic content (TPC), total flavonoid content (TFC), total amide content (TAC), total polyphenol content (TPP), total carotenoids content (TCC), total vitamin $\mathrm{C}$ content (TVC), total vitamin $\mathrm{E}$ content (TVE), total tannins content (TTC) and total xanthophylls content (TXC) were also measured. Overall, all 19 studies showed positive antioxidant activities of $P$. sarmentosum. The characteristics of all studies are summarised in Table 1.

\section{PIPER SARMENTOSUM AS AN ANTIOXIDANT}

Out of 19 studies included in this review, one study tested the antioxidant effect of PS shoot (Sulaiman et al. 2011); one study compared the antioxidant effect between PS fruit and leaf (Hussain et al. 2010); one study compared the antioxidant activities between PS root, stem, leaf and fruit (Hussain et al. 2009); while the other sixteen studies used only PS leaves. The fruit of PS had highest antioxidant activities compared to the root, stem and leaf (Hussain et al. 2009). Hussain et al. (2009) also used different types of solvent for extraction of different parts of PS. Ethanol extracts of different parts of PS showed higher antioxidant activity as well as higher amount of polyphenols, flavonoids and amide compared to aqueous extracts of PS (Hussain et al. 2009). In another study, acetone extract of PS had the highest antioxidant activity followed by ethanol, methanol and aqueous extracts (Sulaiman et al. 2011). Whereas other studies found that methanol extract had the highest antioxidant activity followed by hexane, dichloromethane and ethyl acetate extracts (Yeo et al. 2018). Lee et al. (2014) showed that methanol extract of PS had higher antioxidant activity compared to aqueous, hexane, chloroform, ethyl acetate and butanol extracts. The types of solvent used for extraction influence the efficiency of the extraction of polyphenols and subsequently the 


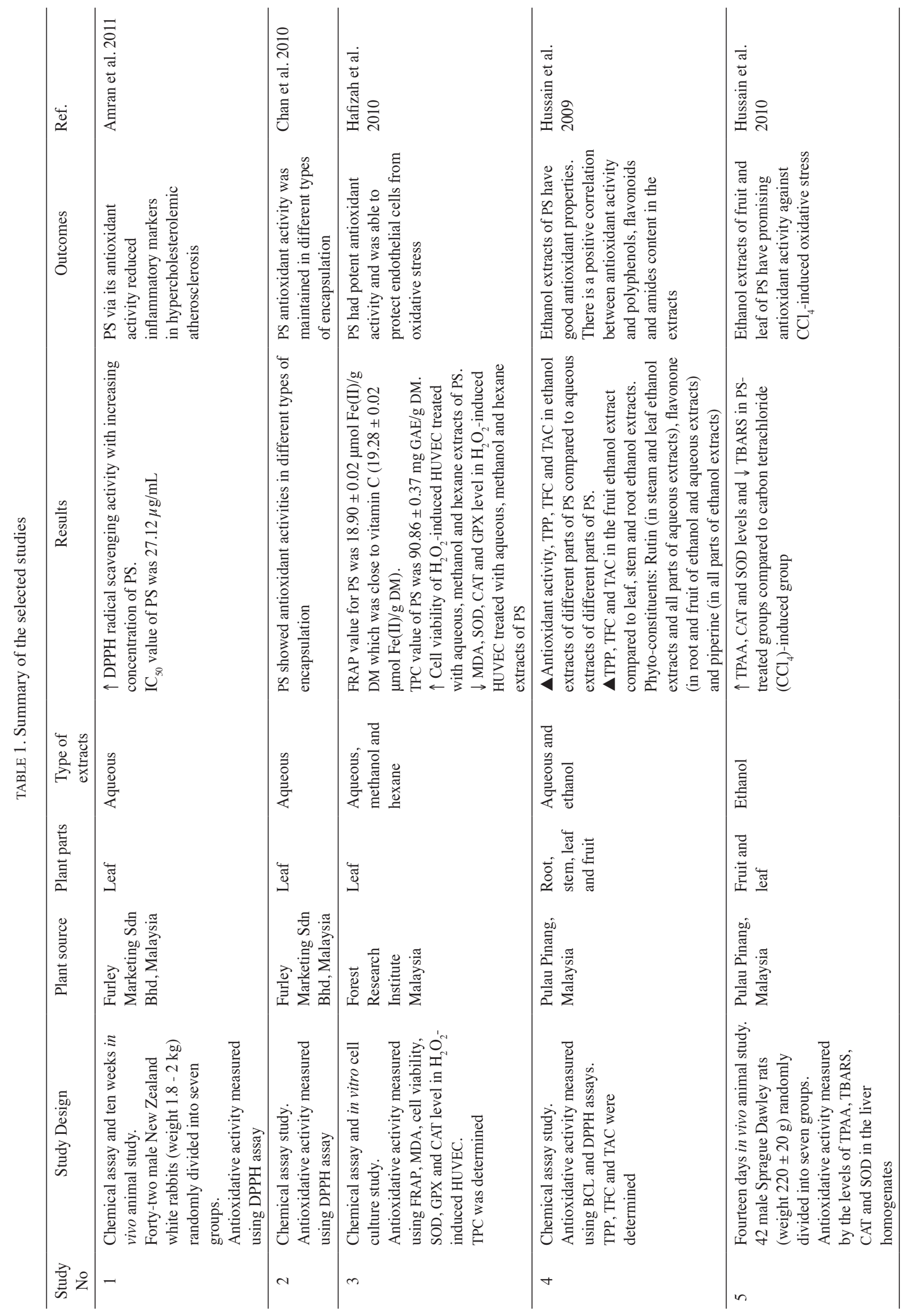




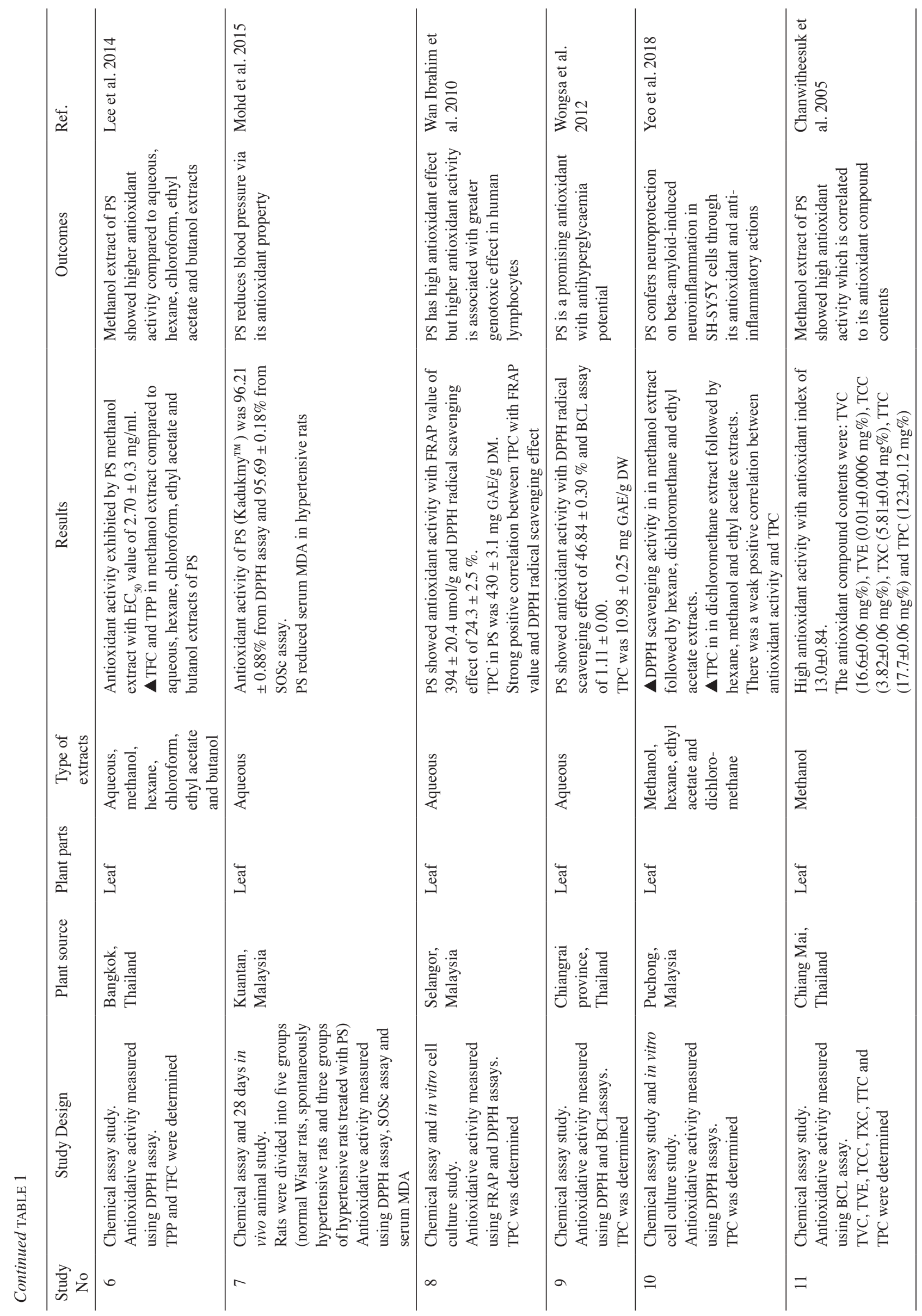




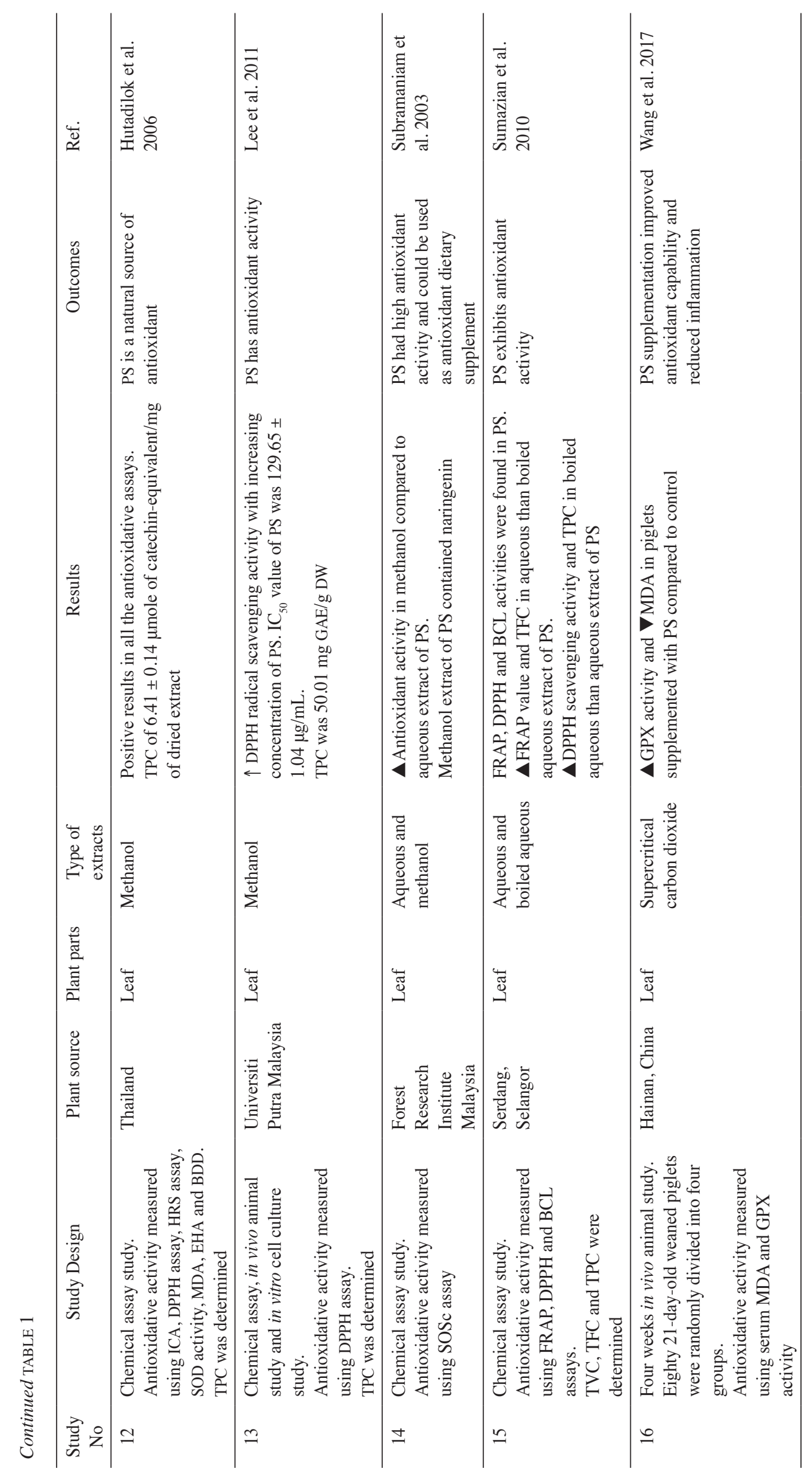




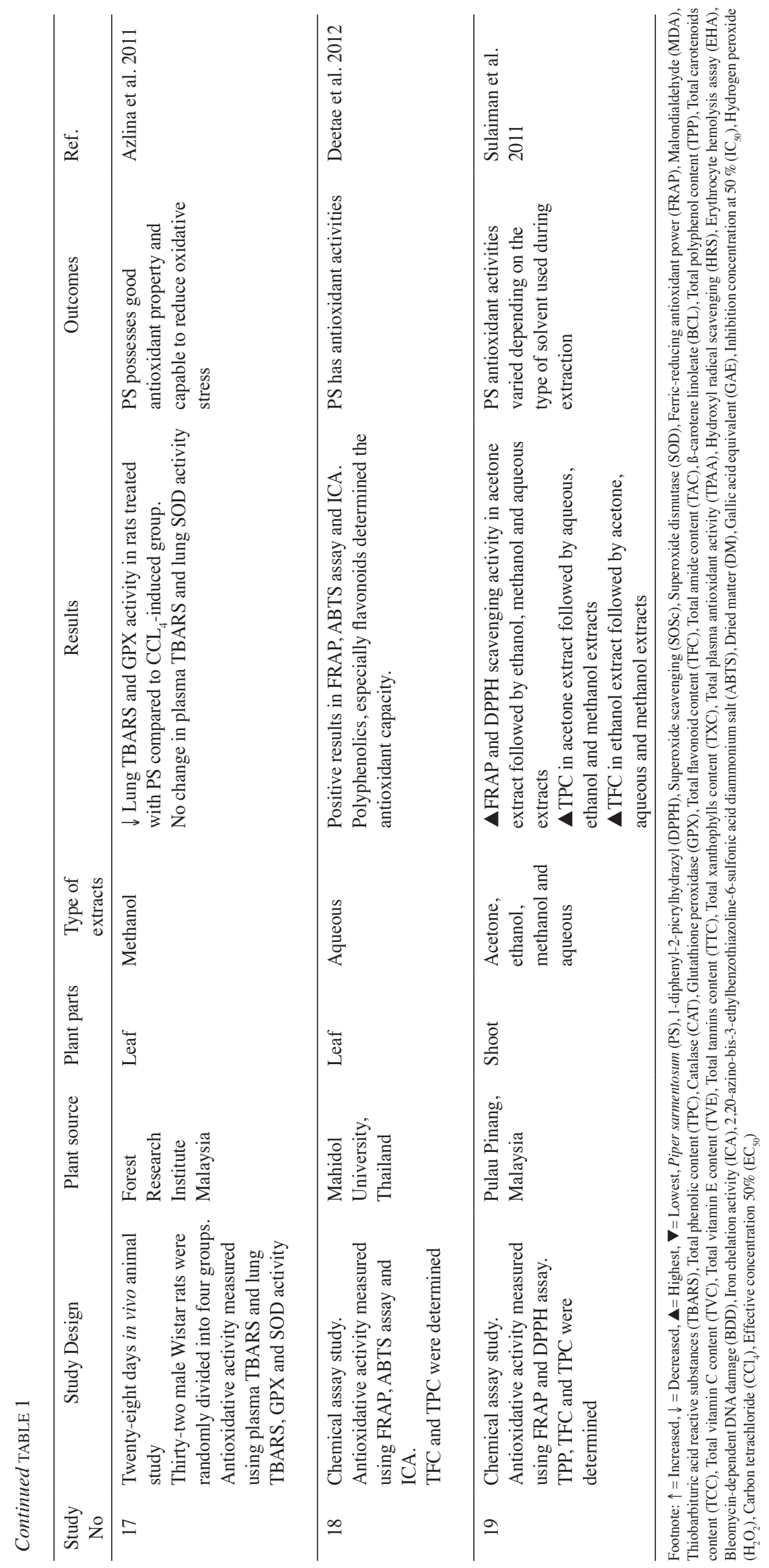


extract's antioxidant properties (Druzynska et al. 2007). Therefore, antioxidant capacity values should only be compared when the measurements have been made by the same method in the same solvent (Perez-Jimenez \& Saura-Calixto 2006).

As listed in Table 1, PS samples used for the antioxidant analyses originated from Malaysia, Thailand and China but mostly were from Malaysia. Twelve out of 19 studies used DPPH radical scavenging assay to determine the antioxidant activity of PS. DPPH radical may be neutralised by direct reduction via electron transfer or by radical quenching via hydrogen atom transfer from the antioxidants (Marxen et al. 2007). The next common antioxidant assay used in the studies was FRAP assay. FRAP assay measures the total antioxidant capacity by calculating the reducing power of ferric to ferrous (Rubio et al. 2016). PS showed FRAP value of $18.90 \mathrm{~mol} \mathrm{Fe}(\mathrm{II}) / \mathrm{g}$ DM which was comparable with vitamin C's FRAP value of $19.28 \mathrm{~mol} \mathrm{Fe(II)/g} \mathrm{DM} \mathrm{(Hafizah}$ et al. 2010). The results of other antioxidant assays used in the studies such as BCL, ABTS, ICA, EHA, HRS and BDD assays followed the similar trend of DPPH and FRAP assays. There is a positive correlation between antioxidant activity and the content of antioxidant compounds in the extracts. Antioxidant activities as measured by DPPH and BCL assays had positive correlation with polyphenols, flavonoids and amides content of PS (Hussain et al. 2009). Whereas FRAP and DPPH assay results were positively affected by total phenolic content of PS (Wan Ibrahim et al. 2010; Yeo et al. 2010). This is in accordance with a previous study that also reported positive correlation between total polyphenols and total flavonoids content with antioxidant effect measured by DPPH assay (Lee et al. 2014).

TBARS and MDA were commonly analysed as markers of lipid peroxidation and oxidative stress (Del Rio et al. 2005). Five of the studies showed that PS was capable to reduce MDA and/or TBARS (Azlina et al. 2011; Hafizah et al. 2010; Hussain et al. 2010; Mohd et al. 2015; Wang et al. 2017). This shows that PS is protective against oxidative stress. In a study done by Mohd et al. (2015), high antioxidant activity of the extract as measured by DPPH assay contributed to its blood pressure-lowering effect as well as reduction of MDA. The antioxidant enzymes; SOD, CAT and GPX represent a first line of defense against reactive oxygen species (ROS) by metabolising them to innocuous byproducts (Ugusman et al. 2011). There are variations among the effects of PS on antioxidant enzymes. PS was reported to increase SOD, CAT and GPX level (Hussain et al. 2010; Wang et al. 2017). Some studies reported that PS reduced SOD, CAT and GPX levels (Azlina et al. 2011; Hafizah et al. 2010). The increased antioxidant enzymes may be attributed to an instant active role of the enzymes in neutralising the ROS. The decreased antioxidant enzyme could be due to the antioxidant compounds in PS that initially played a role in neutralising the ROS, thus reducing the need for enhanced antioxidant enzyme level (Ashokkumar \& Sudhandiran 2008; Hafizah et al. 2010).

Flavonoids are a group of polyphenols that can be found naturally in plants. PS contains flavonoids such as myricetin, quercetin, apigenin (Miean \& Mohamed 2001), naringenin (Subramaniam et al. 2003), rutin and vitexin (Ugusman et al. 2012) that have been proven to have good antioxidant activities. Increased intake of dietary flavonoids is associated with a decrease in the risk of coronary artery disease by $65 \%$ (Arts \& Hollman 2005). Besides, a meta-analysis of prospective cohort studies showed that higher dietary flavonoid intake significantly reduced the risk of stroke (Tang et al. 2016). Rutin and quercetin are more effective than nifedipine in reducing blood pressure and improving oxidative stress markers in high salt diet-induced hypertensive rats (Olallaye et al. 2013). Quercetin has consistent blood pressure-lowering effect in animal and human studies irrespective of the dose, duration or disease status (Clark et al. 2015). Naringenin; a flavonoid present in PS, decreased blood sugar level and oxidative stress markers in diabetic rats (Ren et al.2016). All 19 studies in this review confirmed the antioxidant effect of PS. However, there was no clinical study carried out to investigate the antioxidant effect of PS in human. Therefore, it is recommended that further studies on the antioxidant activities of PS should be carried out in clinical settings. Apart from this, more studies are also needed to identify the specific phytochemical compound responsible for the antioxidant effect.

\section{CONCLUSION}

The review concluded that PS has antioxidant effect and its bioactive compounds such as polyphenols and flavonoids contribute to the antioxidant activities. Thus, PS has the potential to be developed as an alternative treatment for diseases related to oxidative stress such as hypertension, diabetes mellitus and coronary artery disease. A clinical placebo-controlled study may be needed before employing PS as an effective antioxidant.

\section{ACKNOWLEDGEMENTS}

This study was supported by the Fundamental Research Grant Scheme, Ministry of Higher Education, Malaysia (FRGS/1/2014/SKK03/UKM/02/1) and Universiti Kebangsaan Malaysia Medical Centre Fundamental Grant (FF-2017040). Miss Siti Marjiana Ismail receives Ph.D scholarship from the University of Malaya and Ministry of Higher Education, Malaysia.

\section{REFERENCES}

Abd Jalil, M.A., Shuid, A.N. \& Muhammad, N. 2012. Role of medicinal plants and natural products on osteoporotic fracture healing. Evidence-based Complementary and Alternative Medicine 2012: 714512 .

Amran, A.A., Zakaria, Z., Othman, F., Das, S., Al-Mekhlafi, H.M. \& Nordin, N.A.M. 2011. Changes in the vascular cell adhesion molecule-1, intercellular adhesion molecule-1 and c-reactive protein following administration of aqueous extract of Piper sarmentosum on experimental rabbits fed with cholesterol diet. Lipids in Health and Disease 10: 2. https://doi.org/10.1186/1476-511X-10-2. 
Amran, A.A., Zakaria, Z., Othman, F., Das, S., Raj, S. \& Nordin, N.M.M. 2010. Aqueous extract of Piper sarmentosum decreases atherosclerotic lesions in high cholesterolemic experimental rabbits. Lipids in Health and Disease 9: 44.

Ariffin, S.H.Z., Omar, W.H.H.W., Ariffin, Z.Z., Safian, M.F., Senafi, S. \& Wahab, R.M.A. 2009. Intrinsic anticarcinogenic effects of Piper sarmentosum ethanolic extract on a human hepatoma cell line. Cancer Cell International 9(1): 6.

Arts, I.C. \& Hollman, P.C. 2005. Polyphenols and disease risk in epidemiologic studies. The American Journal of Clinical Nutrition 81(1): 317S-325S.

Arunrat, C., Piya, M., Runglawan S. \& Tawatchai T. 2006. Ethnobotany of the Genus Piper (Piperaceae) in Thailand. Ethnobotany Research \& Applications 4: 223-231.

Ashokkumar, P. \& Sudhandiran, G. 2008. Protective role of luteolin on the status of lipid peroxidation and antioxidant defense against azoxymethane-induced experimental colon carcinogenesis. Biomedicine \& Pharmacotherapy 62(9): 590-597.

Azlina, M.F.N., Kamisah, Y., Rahman, R.F.A. \& Faizah, O. 2011. Piper sarmentosum roxb protects lungs against oxidative stress induced by carbon tetrachloride in rats. Journal of Medicinal Plant Research 5(26): 6128-6135.

Chan, E.S., Yim, Z.H., Phan, S.H., Mansa, R.F. \& Ravindra, P. 2010. Encapsulation of herbal aqueous extract through absorption with ca-alginate hydrogel beads. Food and Bioproducts Processing 88(2-3): 195-201.

Chanwitheesuk, A., Teerawutgulrag, A. \& Rakariyatham, N. 2005. Screening of antioxidant activity and antioxidant compounds of some edible plants of Thailand. Food Chemistry 92(3): 491-497.

Clark, J.L., Zahradka, P. \& Taylor, C.G. 2015. Efficacy of flavonoids in the management of high blood pressure. Nutrition Reviews 73(12): 799-822.

Deetae, P., Parichanon, P., Trakunleewatthana, P., Chanseetis, C. \& Lertsiri, S. 2012. Antioxidant and anti-glycation properties of Thai herbal teas in comparison with conventional teas. Food Chemistry 133(3): 953-959.

Del Rio, D., Stewart, A.J. \& Pellegrini, N. 2005. A review of recent studies on malondialdehyde as toxic molecule and biological marker of oxidative stress. Nutrition, Metabolism and Cardiovascular Diseases 15(4): 316-328.

Druzynska, B., Stępniewska, A. \& Wołosiak, R. 2007. The influence of time and type of solvent on efficiency of the extraction of polyphenols from green tea and antioxidant properties obtained extracts. ACTA Scientiarum Polonorum Technologia Alimentaria 6(1): 27-36.

Hafizah, A.H., Zaiton, Z., Zulkhairi, A., Mohd Ilham, A., Nor Anita, M.M.N. \& Zaleha, A.M. 2010. Piper sarmentosum as an antioxidant on oxidative stress in human umbilical vein endothelial cells induced by hydrogen peroxide. Journal of Zhejiang University: Science B 11(5): 357-365.

Hussain, K., Hashmi, F.K., Latif, A., Ismail, Z. \& Sadikun, A. 2012. A review of the literature and latest advances in research of Piper sarmentosum. Pharmaceutical Biology 50(8): 1045-1052.

Hussain, K., Ismail, Z., Sadikun, A. \& Ibrahim, P. 2009. Antioxidant, anti-tb activities, phenolic and amide contents of standardised extracts of Piper sarmentosum Roxb. Natural Product Research 23(3): 238-249.

Hussain, K., Ismail, Z., Sadikun, A. \& Ibrahim, P. 2010. Standardization and in vivo antioxidant activity of ethanol extracts of fruit and leaf of Piper sarmentosum. Planta Medica 76(5): 418-425.
Hussan, F., Mat Zin, N.N., Zullkefli, M.R., Choon, Y.S., Abdullah, N.A. \& Lin, T.S. 2013. Piper sarmentosum water extract attenuates diabetic complications in streptozotocin induced Sprague-Dawley rats. Sains Malaysiana 42(11): 1605-1612.

Hutadilok, T.N., Chaiyamutti, P., Panthong, K., Mahabusarakam, W. \& Rukachaisirikul, V. 2006. Antioxidative and free radical scavenging activities of some plants used in Thai folk medicine. Pharmaceutical Biology 44(3): 221-228.

Lee, J.H., Cho, S., Paik, H.D., Choi, C.W., Nam, K.T., Hwang, S.G. \& Kim, S.K. 2014. Investigation on antibacterial and antioxidant activities, phenolic and flavonoid contents of some Thai edible plants as an alternative for antibiotics. Asian-Australasian Journal of Animal Sciences 27(10): 1461-1468.

Lee, K.H., Padzil, A.M., Syahida, A., Abdullah, N., Zuhainis, S.W., Maziah, M., Sulaiman, M.R., Israf, D.A., Shaari, K. \& Lajis, N.H. 2011. Evaluation of anti-inflammatory, antioxidant and antinociceptive activities of six Malaysian medicinal plants. Journal of Medicinal Plant Research 5(23): 5555-5563.

Marxen, K., Vanselow, K.H., Lippemeier, S., Hintze, R., Ruser, A. \& Hansen, U.P. 2007. Determination of DPPH radical oxidation caused by methanolic extracts of some microalgal species by linear regression analysis of spectrophotometric measurements. Sensors 7(10): 2080-2095.

Miean, K.H. \& Mohamed, S. 2001. Flavonoid (myricetin, quercetin, kaempferol, luteolin, and apigenin) content of edible tropical plants. Journal of Agricultural and Food Chemistry 49(6): 3106-3112.

Mohd, Z.M., Zakaria, Z. \& Megat Mohd Nordin, N.A. 2015. The use of Piper sarmentosum leaves aqueous extract $\left(\right.$ Kadukmy $\left.^{\mathrm{TM}}\right)$ as antihypertensive agent in spontaneous hypertensive rats. BMC Complementary and Alternative Medicine 15: 54.https://doi.org/10.1186/s12906-015-0565-z.

Moher, D., Shamseer, L., Clarke, M., Ghersi, D., Liberati, A. Petticrew, M., Shekelle, P. \& Stewart, L.A. 2015. Preferred reporting items for systematic review and meta-analysis protocols (PRISMA-P) 2015 statement. Systematic Reviews 4(1): 1 .

Nur Syamsina Ahmad, Azlina Abdul Aziz, Kin Weng Kong, Mohamad Shariff A. Hamid, Jadeera Phaik Geok Cheong \& Sareena Hanim Hamzah. 2017. Dose response effect of tualang honey on postprandial antioxidant activity and oxidative stress in female athletes: A pilot study. The Journal of Alternative and Complementary Medicine 23(12): 989-995.

Olaleye, M., Crown, O., Akinmoladun, A. \& Akindahunsi, A. 2014. Rutin and quercetin show greater efficacy than nifedipin in ameliorating hemodynamic, redox, and metabolite imbalances in sodium chloride-induced hypertensive rats Human \& Experimental Toxicology 33(6): 602-608.

Perez-Jimenez, J. \& Saura-Calixto, F. 2006. Effect of solvent and certain food constituents on different antioxidant capacity assays. Food Research International 39(7): 791-800.

Rahman, S.F.S.A., Sijam, K. \& Omar, D. 2016. Piper sarmentosum Roxb.: A mini review of ethnobotany, phytochemistry and pharmacology. Journal of Analytical \& Pharmaceutical Research 2(5): 00031.

Ren, B., Qin, W., Wu, F., Wang, S., Pan, C., Wang, L., Zeng, B., Ma, S. \& Liang, J. 2016. Apigenin and naringenin regulate glucose and lipid metabolism, and ameliorate vascular dysfunction in type 2 diabetic rats. European Journal of Pharmacology 773: 13-23. 
Renugadevi, J. \& Prabu, S.M. 2010. Cadmium-induced hepatotoxicity in rats and the protective effect of naringenin. Experimental and Toxicologic Pathology 62(2): 171-181.

Rubio, C.P., Hernandez-Ruiz, J., Martinez-Subiela, S., Tvarijonaviciute, A. \& Ceron, J.J. 2016. Spectrophotometric assays for total antioxidant capacity (tac) in dog serum: An update. BMC Veterinary Research 12(1): 166.

Sies, H. 1997. Oxidative stress: Oxidants and antioxidants. Experimental physiology 82(2): 291-295.

Subramaniam, V., Adenan, M.I., Ahmad, A.R. \& Sahdan, R. 2003. Natural antioxidants: Piper sarmentosum (Kadok) and Morinda elliptica (Mengkudu). Malaysian Journal of Nutrition 9(1): 41-51.

Sulaiman, S.F., Sajak, A.A.B., Ooi, K.L., Supriatno \& Seow, E.M. 2011. Effect of solvents in extracting polyphenols and antioxidants of selected raw vegetables. Journal of Food Composition and Analysis 24(4): 506-515.

Sumazian, Y., Syahida, A., Hakiman, M. \& Maziah, M. 2010. Antioxidant activities, flavonoids, ascorbic acid and phenolic contents of Malaysian vegetables. Journal of Medicinal Plants Research 4(10): 881-890.

Tang, Z., Li, M., Zhang, X. \& Hou, W. 2016. Dietary flavonoid intake and the risk of stroke: A dose-response meta-analysis of prospective cohort studies. BMJ Open 6(6): e008680.

Ugusman, A., Zakaria, Z., Chua, K., Nordin, N.M.M. \& Mahdy, Z.A. 2012. Flavanoids of Piper sarmentosum and its cytoprotective effects against oxidative stress. EXCLI Journal 11: 705-714.

Ugusman, A., Zakaria, Z., Hui, C.K. \& Megat Mohd Nordin, N.A. 2011. Piper sarmentosum inhibits ICAM-1 and NOX4 gene expression in oxidative stress-induced human umbilical vein endothelial cells. BMC Complementary and Alternative Medicine 2011: 11 . https://doi.org/10.1186/1472-6882-11-31 .

Velioglu, Y., Mazza, G., Gao, L. \& Oomah, B. 1998. Antioxidant activity and total phenolics in selected fruits, vegetables, and grain products. Journal of Agricultural and Food Chemistry 46(10): 4113-4117.

Wan Ibrahim, W.I., Sidik, K. \& Kuppusamy, U.R. 2010. A high antioxidant level in edible plants is associated with genotoxic properties. Food Chemistry 122(4): 1139-1144.
Wang, D.F., Zhou, L.L., Zhou, H.L., Hou, G.Y., Zhou, X. \& Li, W. 2017. Effects of Piper sarmentosum extract on the growth performance, antioxidant capability and immune response in weaned piglets. Journal of Animal Physiology and Animal Nutrition 101(1): 105-112.

Wongsa, P., Chaiwarit, J. \& Zamaludien, A. 2012. In vitro screening of phenolic compounds, potential inhibition against $\alpha$-amylase and $\alpha$-glucosidase of culinary herbs in Thailand. Food Chemistry 131(3): 964-971.

Yeo, E.T.Y., Wong, K.W.L., See, M.L., Wong, K.Y., Gan, S.Y. \& Chan, E.W.L. 2018. Piper sarmentosum Roxb. confers neuroprotection on beta-amyloid (A $\beta$ )-induced microglia-mediated neuroinflammation and attenuates tau hyperphosphorylation in SH-SY5Y cells. Journal of Ethnopharmacology 217: 187-194.

Siti Marjiana Ismail, Chua Kien Hui, Amilia Aminuddin \& Azizah Ugusman*

Department of Physiology

Faculty of Medicine

Universiti Kebangsaan Malaysia Medical Centre

Jalan Yaacob Latiff, Bandar Tun Razak

56000 Cheras, Kuala Lumpur, Federal Territory

Malaysia

Siti Marjiana Ismail

Institute of Biological Sciences

Faculty of Science

University of Malaya

50603 Kuala Lumpur

Malaysia

*Corresponding author; email: dr.azizah@ppukm.ukm.edu.my

Received: 31 March 2018

Accepted: 5 June 2018 